How to cite: Sabău, D.A., Haidu, I., Şerban, Gh. (2020) Key Types of Anthropic Influence on Surface Waters, Components of Spatial Decision Support System for Prevention and Management of Floods (Firiza Basin). 2020

"Air and Water - Components of the Environment" Conference Proceedings, Cluj-Napoca, Romania, p. 177-190, DOI: 10.24193/AWC2020_17.

\title{
KEY TYPES OF ANTHROPIC INFLUENCE ON SURFACE WATERS, COMPONENTS OF SPATIAL DECISION SUPPORT SYSTEM FOR PREVENTION AND MANAGEMENT OF FLOODS (FIRIZA BASIN)
}

\author{
Daniel Andrei $S A B \breve{A} U^{1,2}$, Ionel HAIDU ${ }^{3}$, Gheorghe ŞERBAN ${ }^{l}$
}

DOI: 10.24193/AWC2020_17

\begin{abstract}
In the current climate change context, setting up a real time spatial decision support system for flood prevention and management is more than a necessity. One of the components of this system would be represented by the anthropic influence on the water courses in the territory, respectively by the reservoirs, the regularization structures, the consolidation of the river banks, the water supply system, the use of land etc. The introductory part of the article presents literature related to the chosen subject, information on the spatial location of the study basin, as well as technical details on the spatial organization of the Firiza hydro-technical system. The following chapter shows the methodological structure and databases, which have made it possible to carry out the study. A particular emphasis is placed on the virtual environment (statistical, spatial modelling and hydrological/hydraulic modelling software). The study continues with the presentation of the anthropogenic influence structure, organized at detail level for each type of anthropic intervention separately, in a compatible format, connectable to the other modules related to the spatial system decision support. Relevant case studies on the restoration of liquid runoff, the degree of attenuation of the flood waves, the behavior of water uses and hydro-technical structures, etc., were done - elements that prove the efficiency of the functioning of the anthropic intervention components (analysis carried out based on data from the water resources monitoring network in the river basin). The conclusions reveal that the accuracy of future models (hydrological, optimization, hydraulic, potential damage assessment etc.) depends in good measure on the thorough knowledge of the components of anthropic influence on water resources, in addition to the quality of input data and the expertise of the hydrologist.
\end{abstract}

Keywords: surface water resources, hydro-technical system, influenced runoff, spatial databases, hydrological models, decision support system.

\section{INTRODUCTION}

\subsection{Anthropic influence on surface waters and management of floods}

Given the human dependence on water resources and the need to manage hydrological hazards (Băloiu, 1980; Chiriac et al., 1976; Șerban et al., 2004) the anthropic influence on surface waters is an intensively debated aspect over several decades.

\footnotetext{
${ }^{1}$ Babeş-Bolyai University, Faculty of Geography, 5-7 Clinicilor, 400006, Cluj-Napoca, Romania, email: sabau.daniel@ubbcluj.ro,gheorghe.serban@ubbcluj.ro

${ }^{2}$ Romanian Waters National Administration - Someş-Tisa Water Branch, 7 Vânătorului, 400213, Cluj-Napoca, Romania., e-mail: andrei.sabau@dast.rowater.ro

${ }^{3}$ University of Lorraine, Laboratory LOTTER - EA 7304, 57045 Metz, ionel.haidu@ univ-lorraine.fr
} 
If some older or newer publications refer to the methodology for studying and monitoring the waters and the related watersheds, being elaborated by specialized institutes and official state administrations (see the instructions elaborated in 1980 and 1988 , etc.), others are focused on specific issues related to the anthropic influence on water or the management of hazards as well as other problems related to water resources management (Diaconu, 1999; Fall et al., 2003; Șerban and Gălie, 2006; Soncini-Sessa et al., 2007; Bizzi et al., 2012; Calijuri et al., 2015; Fekete and Bogárdi, 2015 etc.).

The vast expertise accumulated in the utilization of complex hydrotechnical systems led to reports, regional studies or articles, which capture various problems related to the anthropic influence on the watercourses (Sofronie, 2000; Şerban, 2007; Șerban and Touchart, 2008; Horvath, 2008; Pandi, 2011 etc.).

As the problem of hydrological hazards and risks and their management has become extremely sensitive particularly in the last decades, various authors were motivated to conduct theoretical or applied research works on this topic (Şelărescu and Podani, 1993; Petry, 2002; Stănescu and Drobot, 2002; Marchia et al., 2010; Sorocovschi, 2017; Esposito and Di Pinto, 2014; Dumitrache et al., 2018).

The effects of floods can be mitigated, reducing the loss of human life and property damage, by applying two categories of prevention and control measures (Băloiu, 1971; Chiriac et al., 1976; Şelărescu and Podani, 1993; Stănescu and Drobot, 2002; Marchia et al., 2010; Sorocovschi, 2016; 2017 etc.).

Structural measures involve the building of hydrotechnical constructions in the river bed and/or in the river basin. Non-structural measures include flood forecasting, population warning and emergency planning, control of territorial planning and management of flood prone areas, flood insurance for flood vulnerable people, etc. In the context of the non-structural measures, the flood forecasting and the population warning depend on complex social, economic and environmental conditions (Şelărescu and Podani, 1993; Stănescu and Drobot, 2002; Sorocovschi, 2016; 2017 etc.).

Prior to 2006, the Romanian flood monitoring and management system was largely based on manual monitoring methods and data collection.

The novel component of the DESWAT (Destructive Water Abatement and Control of Water Disasters) project, started in 2001 to improve hydrological hazard monitoring and management activities, is the hydrological data provided in real time by the automatic stations. With DESWAT, managers are able to supplement their forecasting experience with the predictive power of computer-based forecasting models.

The next step for Romania will be the implementation of an integrated water management system (concept emerged in the first years of the 21st century), on the basis of SIMIN (Integrated National Meteorological System), a model of meteorological monitoring and forecasting, completed in 2004. Special attention will be given to the tasks to be undertaken for the development and demonstration of SDSS tools in the WATMAN (Information System for Integrated Water Management - Stage I) project started in 2003.

\subsection{Spatial location of study area}

The Firiza river basin, located in the Igniş Mountains, was chosen as the case study for our approched topic. This basin is a natural area characterized by high precipitation 
and water runoff rates. The following aspects were taken into account in the selection of this basin: the complexity of the physical-geographical factors, the existence of several altitude levels, the presence of important human settlements, the existence of reservoirs, and, last but not the least, the available hydrometeorological data.

The northern limit of the Baia-Mare Territorial Administrative Unit overlaps approximately with the water divide of the Firiza river basin (Fig. 1).

The registered watercourses from the basin have the specific characteristics of torrential flows, with very high average slopes (Table 1).

Table 1. The morphometric and morpho-hydrographic elements of the main watercourses in the Firiza basin (source, Cadastral Atlas of Waters and Somes-Tisa W.B.A)

\begin{tabular}{|c|c|c|c|c|c|c|c|c|}
\hline \multirow{3}{*}{$\begin{array}{l}\text { Crt. } \\
\text { No }\end{array}$} & \multirow{3}{*}{ River } & \multicolumn{4}{|c|}{ Watercourse } & \multicolumn{2}{|c|}{ Watershed } & \multirow{3}{*}{$\begin{array}{c}\text { Precipitation } \\
\text { Annual average at } \\
\text { Firiza gauging } \\
\text { station }(\mathbf{m m}) \\
1970-2019\end{array}$} \\
\hline & & \multirow{2}{*}{$\begin{array}{c}\text { Lenght } \\
(\mathbf{k m})\end{array}$} & \multicolumn{2}{|c|}{ Altitude (m) } & \multirow{2}{*}{$\begin{array}{c}\text { Average } \\
\text { slope (\%) }\end{array}$} & \multirow{2}{*}{$\begin{array}{l}\text { Area } \\
\left(\mathbf{k m}^{2}\right)\end{array}$} & \multirow{2}{*}{$\begin{array}{c}\text { Average } \\
\text { altitude (m) }\end{array}$} & \\
\hline & & & Spring & Mouth & & & & \\
\hline 1 & Pistruiţa & 6 & 1033 & 480 & 92 & 17 & 912 & \multirow{4}{*}{1156} \\
\hline 2 & Valea Neagră & 7 & 880 & 415 & 66 & 24 & 792 & \\
\hline 3 & Jidovaia & 7 & 1080 & 280 & 114 & 12 & 731 & \\
\hline I & Firiza & 28 & 1180 & 265 & 33 & 168 & 743 & \\
\hline
\end{tabular}

Although major floods have occurred over the years, such as in the years 1970, 1993, 2001, 2013 (causing significant damages - millions of euros in the last 20 years only), no flood warning system based on numerical models has been implemented to reduce damages in the city of Baia Mare (Table 2).

Table 2. The assessment of damages recorded during the period 1995-2019 in the Firiza basin (source Someş-Tisa W.B.A - W.M.S Maramureș, 2019)

\begin{tabular}{|c|c|c|c|c|}
\hline Year & $\begin{array}{c}\text { Administrative } \\
\text { unit }\end{array}$ & Locality & Watershed & Damage (lei) \\
\hline 1995 & \multirow[t]{5}{*}{ Baia Mare } & \multirow[t]{4}{*}{ Baia Mare } & \multirow[t]{6}{*}{ Firiza } & 58.000 \\
\hline 1998 & & & & 730.000 \\
\hline 2001 & & & & 52.862 .345 \\
\hline 2004 & & & & 25.000 \\
\hline 2013 & & Valea Neagra & & 500.000 \\
\hline \multicolumn{3}{|r|}{ Total } & & 54.175.345 \\
\hline
\end{tabular}

\subsection{Firiza hydro-technical system}

The Strâmtori Dam, on the Firiza river, is the main component of the Baia Mare hydro-technical system (Fig. 2).

The construction was designed and completed between 1960-1964, with the main purpose of ensuring the necessary supply of drinking and industrial water for the Baia-Mare mining micro-region and for electricity generation as well. Located $10 \mathrm{~km}$ upstream of the Baia Mare city center, it is a concrete mushroom-head buttress dam of $51.50 \mathrm{~m}$ maximum height and $260 \mathrm{~m}$ length at top of dam.

Although the Strâmtori-Firiza reservoir has a gross volume at Normal retention level (N.N.R) of 15.938 million $\mathrm{m} 3$, the parameters determined by the operating conditions 


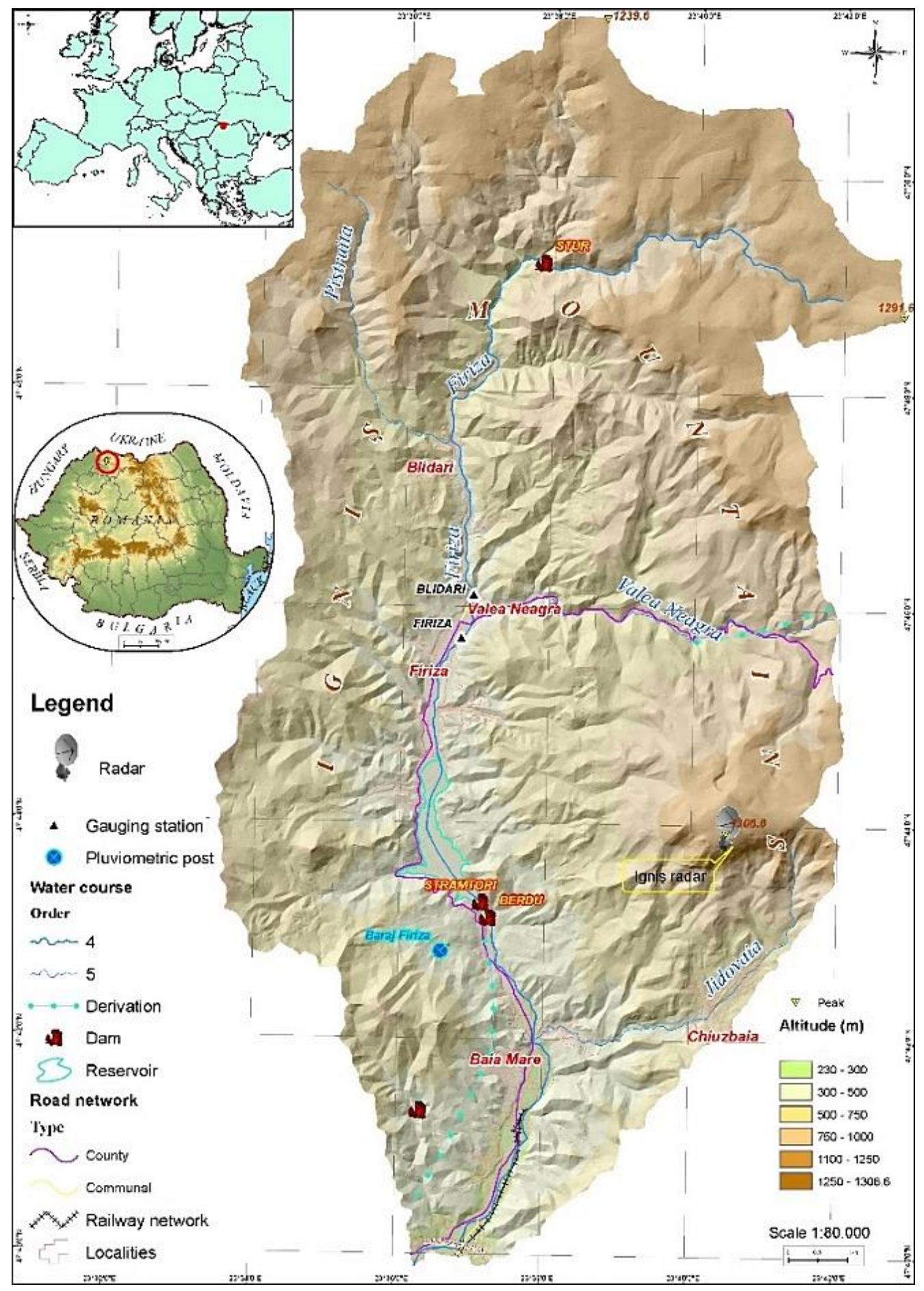

Fig. 1. General map of the Firiza watershed (heigh source Topo Map RO \& PPPDI-DEM, 2013). 
restrict the attenuation volume to only 0.849 million $\mathrm{m} 3$. The flood defense of the objectives downstream of the dam (the city of Baia-Mare with a population of about 120,000 people), is achieved by exploiting the reservoir under high water conditions.

Under high water conditions, flood protection is performed by using the spillways that can release a maximum flow of $270 \mathrm{~m}^{3} / \mathrm{s}$, operations conditioned by the limited transport capacity of the riverbed downstream of the dam $\left(110 \mathrm{~m}^{3} / \mathrm{s}\right)$.

From the major dams in the A importance level existing in the Someş river basin, Stramtori Firiza is the only one situated in the immediate vicinity of a large town. Moreover, it is the oldest dam, which highlights the need for rehabilitation and conditional exploitation.

The modernized hydrometeorological monitoring network present in the basin favors the organization of a SDSS, considering that in 2004 the Doppler type meteorological radar equipment, installed near Baia Mare, on the Igniș Peak, started functioning.

Additionally, two automatic gauging stations with sensors at Blidari and Firiza, infrastructure developed in 2007 within the DESWAT hydrological project, provide the necessary precise information with a very high frequency.

\section{DATA AND METHODS}

\subsection{Cartographic database}

Concerning the cartographic database, the following types of maps were used for setting up the complete SDSS support:

a) topographic maps 1: 25,000; from which altimetry elements were digitized;

b) pedological maps 1: 200,000, which represented the support for the creation of a digital database on soil type, texture; the map sheet superimposed on the study basin is L-34-VI Baia-Mare;

c) Corine Land Cover 2018 database for the analysis of the land use, realized on scale 1: 100,000;

d) color orthophotoplanes 2007, 2015, 2018 for the analysis of the land use and the overlay of the flood risk bands, realized on scale 1: 100,000 - a product made by the National Agency for Cadastre and Real Estate Advertising (ANCPI) resulting from the aerophotography works.

\subsection{Topographic database}

The following topographic data were used in the study: digital terrain model with a spatial resolution of $3 \mathrm{~m}$, transversal profiles and surveys of bridges on the Firiza river. The raw data were generated within the project "Plan for the Prevention, Protection and Mitigation of Flood Effects in the Somes-Tisa River Basin", a national project funded by AXA 5 POS Environment (POS - Sectorial operational program).

\subsection{Meteorological and hydrological data}

The following types of hydrometeorological data were used for the entire SDSS support: 


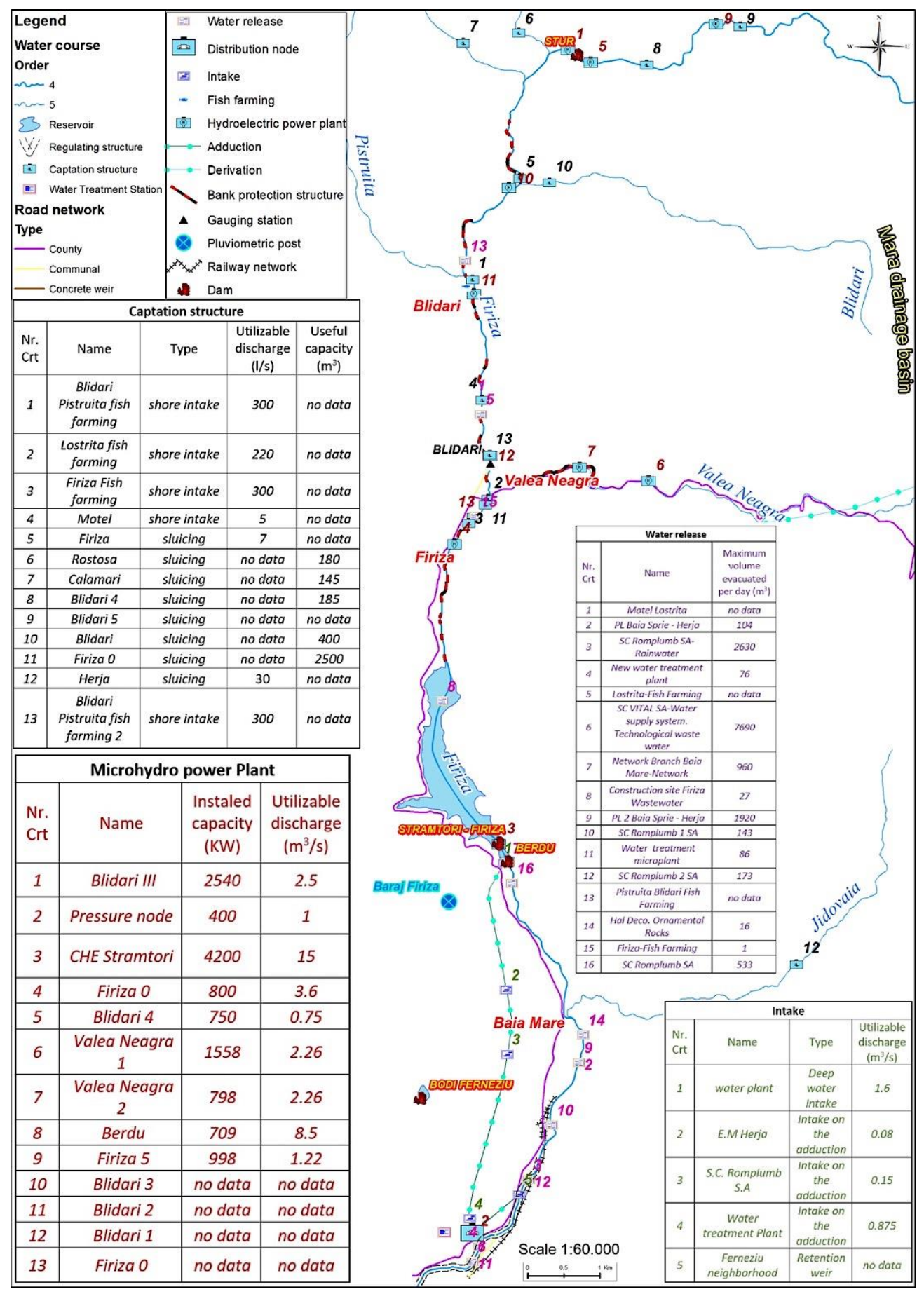

Fig. 2. Firiza hydro-technical system (data, "Someș-Tisa" Water Basin Administration, 2019). 
a) meteorological data recorded at the weather stations within and near the study basin. Some other sources (National Climatic Data Center, RP5, ECAD) were used, too, from which information was extracted regarding the weather stations Baia Mare, Ocna Şugatag and Sighetul Marmatiei.

b) RADAR database, provided by the automatic Doppler equipment (in band C) of German origin - Gematronik, from Igniş Peak, with the Dual Polarization System. It is considered by specialists to be essential for the supply of complex and reliable data, necessary both for the preparation of weather forecasts and as input data for the hydrological forecast;

c) hydrological data from the gauging stations in the basin and various types of installations and constructions, other characteristic curves.

\subsection{Software products, extensions, functions, methods and techniques applied}

After collecting the data, the primary GIS database was developed (hydrographic network, the vector geological component, the vector soil component, vector land cover - CLC 1990-2018 -), followed by the derived GIS database (digital elevation model, land slope, the slopes orientation).

An essential condition for the functioning of a model (hydrological, hydraulic, geomorphological, climatic, etc.) in GIS, HEC-HMS, HEC-RAS etc., is that the spatial resolution of the parameters that make up the model are the same.

The hydrological modeling using GIS techniques falls within the scope of spatial analysis. Most GIS software comes with spatial analysis feature packages (Spatial Analyst - for ArcGIS, Terrain Anaysis - SagaGIS, Spatial Analysis - for Idrisi, etc.).

\section{RESULTS AND DISCUSSIONS}

While the planning, design, construction and operation of most structural measures for flood prevention and control can be done using defined mechanisms, the decisions pertaining the non-structural measures, in particular the forecasting and flood warning, are complex and not uniquely defined. Therefore, such decisions require the support of mathematical models, with quantitative as well as qualitative stages of decision modeling. These decisions can be efficiently reached by using a Spatial Decision Support System (SDSS - Fig. 3).

The classic definition of an DSS provided by Sprague and Carlson (1982) is "an interactive computer-based support system that helps decision makers use data and models to solve unstructured problems."

One of the general formal definitions made by Loucks and da Costa (1991) is that DSSs are "computer-based tools, having interactive, graphic and modeling features, to address specific problems and to assist specialists in their study and the search for a solution to the problems they are facing ". 
Simonovic (1999) recommended the following description of a decision support system in the context of decision making regarding water resources: "It is a system that allows decision makers to combine personal judgment with computer outputs through a computerized interface to produce information for decision making" .

At present, when we talk about decision support systems, it is clearly understood that they are computer based systems, capable of improving the efficiency of the decision making process (Todini et al, 1999; De Deus et al., 2016).

\subsection{Key types of anthropic influence on surface waters from Firiza river basin}

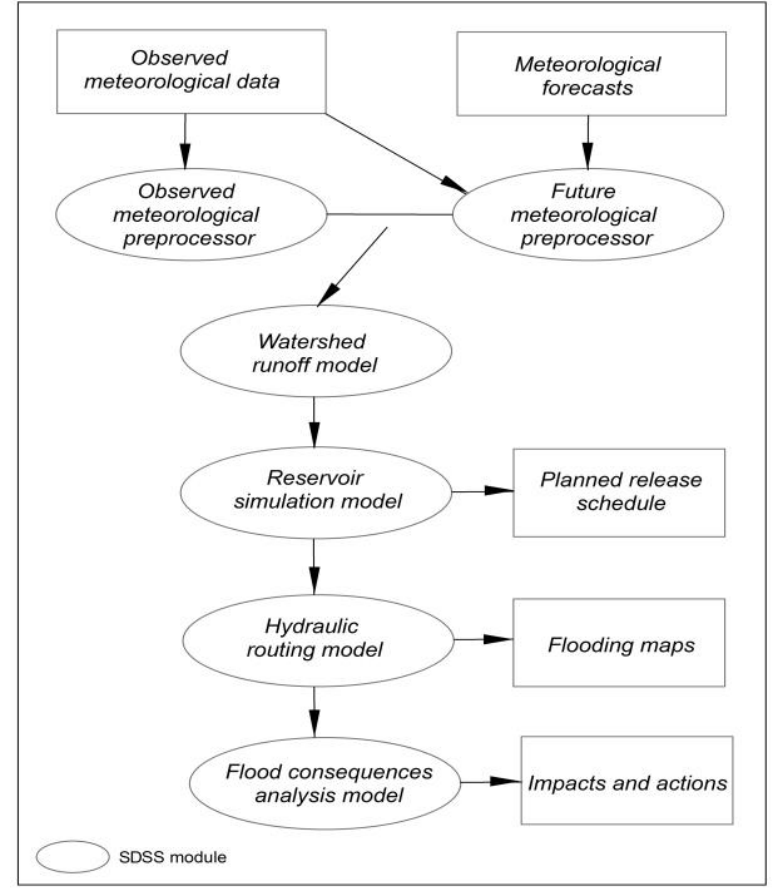

Fig. 3. General schema and components of a SDSS.

Starting from the literature and from the aforementioned considerations, several types of anthropic influence have been identified in the Firiza river watershed, corresponding to the main components of the SDSS model (Table 3).

Within the model of the flow in the basin, several types of anthropic influence are identified, of obvious impact on the flow (temporal and spatial dynamics of land use (cover) types, additional water supply in the basin for the purpose of complex utilization, the use of water in hydropower, etc.).

For the model of simulation in reservoirs, their capacity and the handling of the dam installations prove decisive, both in the flow redistribution in time and in the case of flood waves attentuation. The two charts modeled in HEC-HMS support these facts.

Within the hydraulic propagation model a decisive role is played by the hydrotechnical structures and the land use. Substantial changes in the propagation of the flood waves can be noticed under the effect of these structures. Furthermore, the differences in land roughness, the obstructions imposed by various civil constructions, as well as the areas of water accumulation contribute to the modification of the concentrated flow.

For the model of analysis of the flood effects, the major impact is caused by the changes of structural and non-structural source within the flood prone area. The 
Tabel 3. Key types of anthropic influence and effects induced in the structure of a SDSS

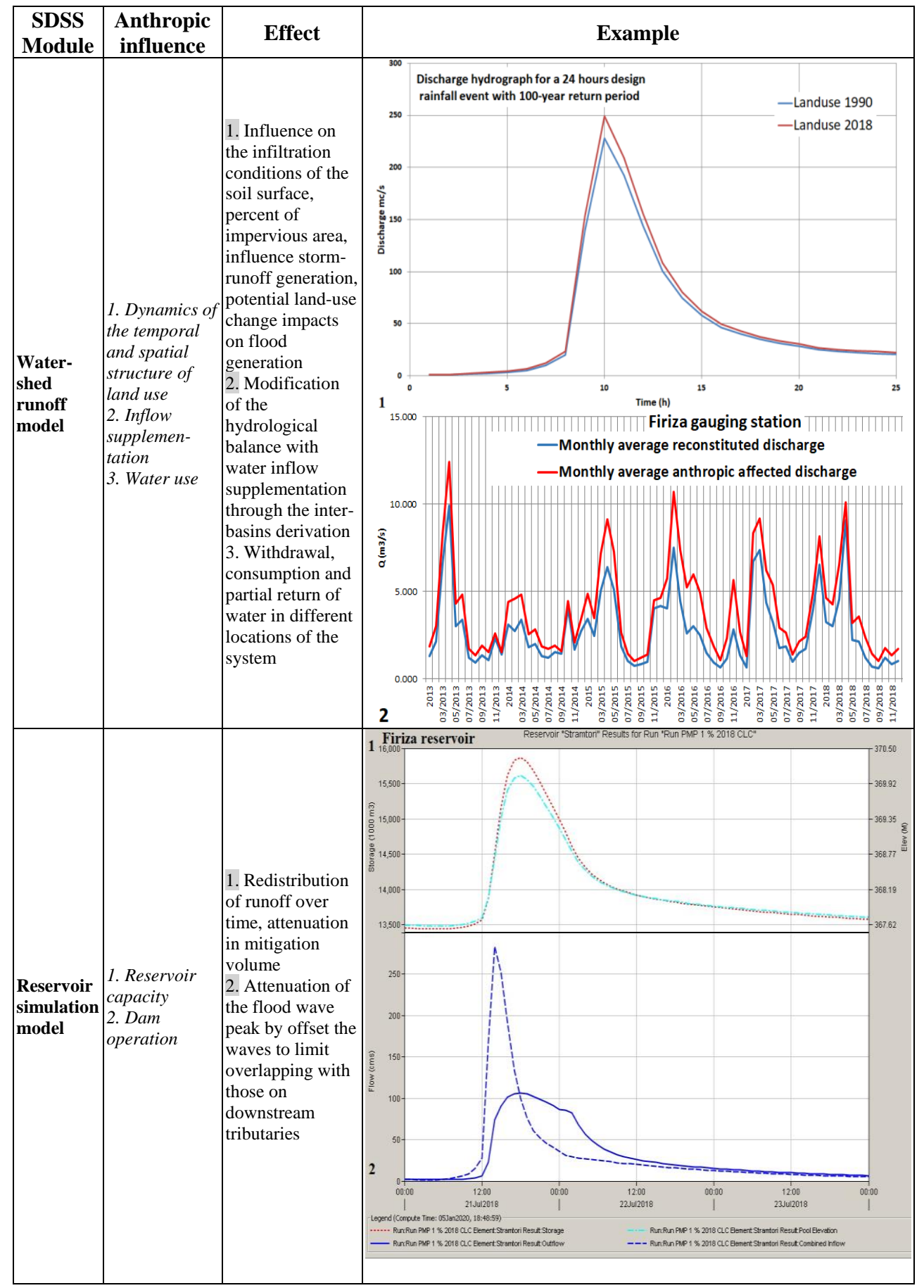




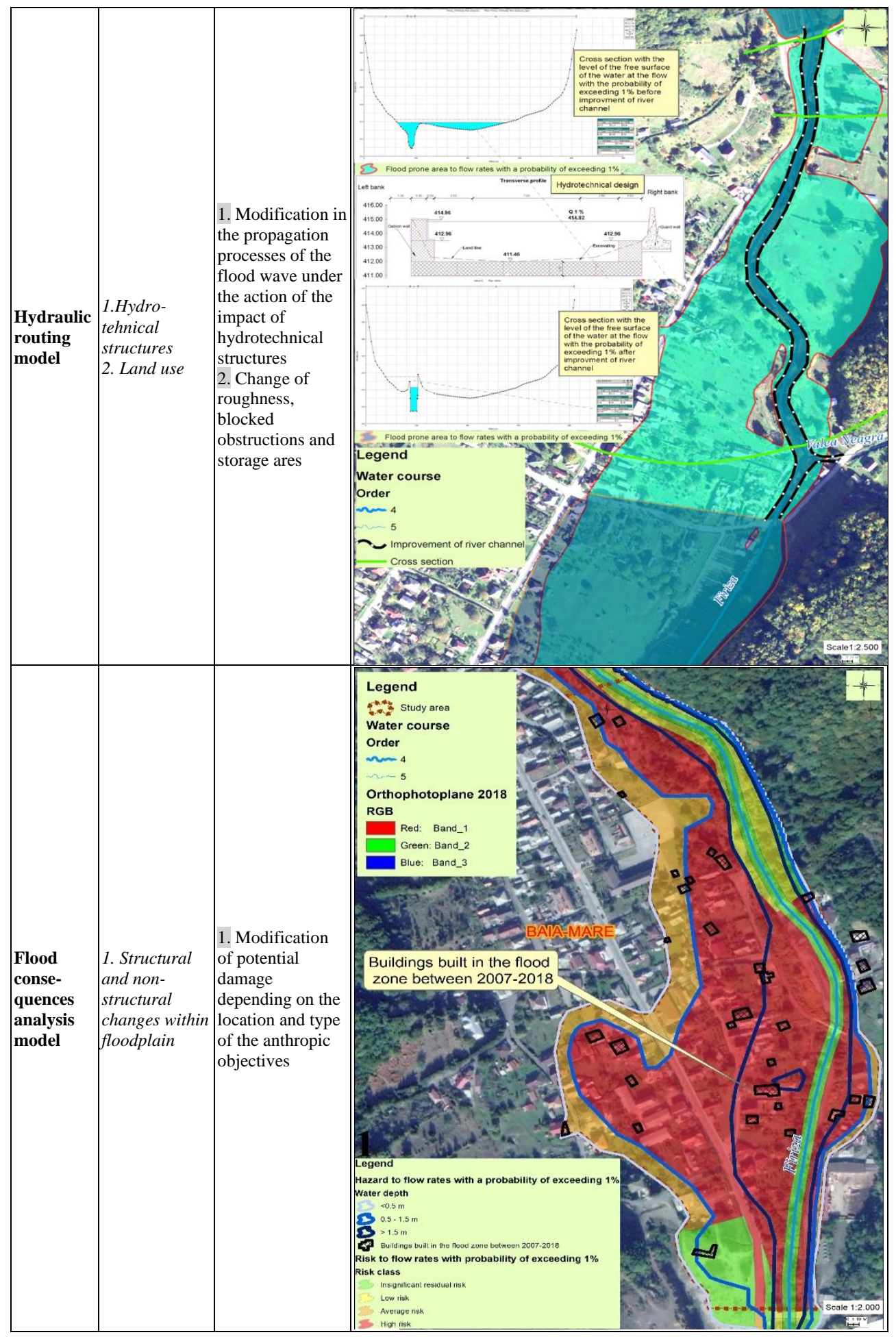


destructive potential level depends on the location and type of the anthropic objectives.

\section{CONCLUSIONS}

Along with climate change, the risk of flooding is also influenced by the anthropic factor, in this case the development of urban areas and other significant land use changes.

These will lead to accelerated water flow and the production of high water volumes, which will reach the watercourses.

Also, a major impact will have the building of new constructions in the floodplain, the population increase in the flood risk areas, the degradation in time of the flood protection infrastructure that can lead to a system failure.

The accuracy of future models (hydrological, optimization, hydraulic, potential damage assessment etc.) will depend in good measure on the thorough knowledge of the components of anthropic influence on water resources, in addition to the quality of input data and the hydrologist's expertise.

\section{ACKNOWLEDGEMENTS}

We thank the "Someș-Tisa" Water Basin Administration for the provided technical and informational support, the Maramures Water Management System for information regarding the hydrotechnical system Firiza and BabeșBolyai University for the software support and the PC technique available for modeling.

\section{REFERENCES}

1. Băloiu, V. (1980) Amenajarea bazinelor hidrografice şi a cursurilor de apă [The arrangement of river basins and watercourses,] Edit. Ceres, București.

2. Bizzi, S., Pianosi, F., Soncini-Sessa, R. (2012), Valuing hydrological alteration in multi-objective water resources management. Journal of Hydrology, Volumes 472-473, 277-286, https://doi.org/10.1016/j.jhydrol.2012.09.033

3. Calijuri, M.L., de Siqueira Castro, J., Soares Costa, L., Peixoto Assemany, P., Mattos Alves, J.E. (2015), Impact of land uselland cover changes on water quality and hydrological behavior of an agricultural subwatershed. Environmental Earth Sciences, Volume 74, 5373-5382, https://doi.org/10.1007/s12665-015-4550-0

4. Chiriac V., Filotti A., Teodorescu I. (1976), Lacuri de acumulare [Reservoirs], Edit. Ceres, Bucureşti.

5. De Deus, L., de Britto, F., dos Santos, C., de Melo França, C., Andrade, C., Ferreira, V., de Berrêdo Viana, D., de Freitas, M. (2016) GeoAmazonas-GIS for Water Resources Manag. Journal of Geographic Information System, 8, 558-577. doi: 10.4236/jgis.2016.85047 
6. Diaconu S. (1999), Cursuri de apă. Amenajare, impact, reabilitare [Watercourses, arrangement, impact, rehabilitation], Edit. $\mathrm{H}^{*} \mathrm{G}^{*} \mathrm{~A} *$, Bucureşti

7. Dumitrache, Ramona; Ion, Bogdan; Godeanu, Elena (2018), Strengthening Cooperation Between River Basin Management Planning and Flood Risk Prevention to Enhance the Stats of Waters of the Tisza River Basin. International Multidisciplinary Scientific Geo Conference: SGEM, Sofia, Vol. 18, Iss. 3.1, 655-661, DOI:10.5593/sgem2018/3.1/S12.085

8. Esposito, A., Di Pinto, V. (2014), Urban Resilience and Risk Assessment: How Urban Layout Affects Flood Risk in the City. 2014 14th International Conference on Computational Science and Its Applications, Guimaraes, Portugal, DOI: 10.1109/ICCSA.2014.46

9. Fall, O., Hori, N., Kan, H., Diop, M. (2003), Toward an Integrated Management Plan of the Djoudj Park Water Resources: Senegal River Mouth. Environmental Management, Volume 31, 14-28, https://doi.org/10.1007/s00267-002-2750-3

10. Fekete, B.M., Bogárdi, J.J. (2015) Role of engineering in sustainable water management. Earth Perspectives, Volume 2, 1-9, https://doi.org/10.1186/s40322-0140027-7

11. Horváth, Cs. (2008), Studiul lacurilor de acumulare din bazinul superior al Crişului Repede [Study of reservoirs in the upper basin of Crisul Repede], Edit. Casa Cărţii de Ştiinţă, Cluj-Napoca, 208 p.

12. Loucks, D.P., da Costa, J.R. (1991), Computer-Aided Decision Support in Water Resources Planning and Management. In "Decision Support Systems: Water Resources Planning”, edited by Loucks, D. P., and da Costa, J. R, NATO ASI Series, published by Springer-Verlag, Berlin, Germany.

13. Marchia, L., Borga, M., Precisoa, E., Gaume, E. (2010), Characterisation of selected extreme flash floods in Europe and implications for flood risk management. Journal of

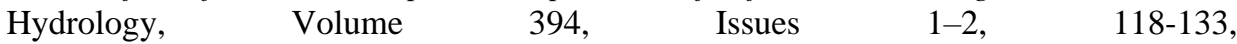
https://doi.org/10.1016/j.jhydrol.2010.07.017

14. Pandi, G. (2011), The influenced flow regimes, 2011 "Air and Water - Components of the Environment" Conference Proceedings, Cluj-Napoca, Romania, p. 38-44

15. Petry, B. (2002), Keynote lecture: Coping with floods: complementarity of structural and non-structural measures. Flood Defence 2002, Wu et al. (eds) (C) 2002 Sci. Press, New York Ltd., 60-70

16. Simonovic, S. (1996), Decision Support Systems for Sustainable Management of Water Resources: 1. General Principles, Water International 21(4):223-32.

17. Sofronie, C. (2000) Amenajări hidrotehnice în bazinul hidrografic Someş-Tisa [Hydrotechnical arrangements in the Someș-Tisa watershed], Casa de editură Gloria, Cluj-Napoca.

18. Soncini-Sessa, R., Weber, E., Castelletti, A. (2007), Integrated and Participatory Water Resources Management - Theory. Developments in Integrated Environmental Assessment, Volume 1A, Elsevier.

19. Sorocovschi. V. (2017), Fenomene și procese hidrice de risc. Partea I - Domeniul continental [Hydraulic risk phenomena and processes], Edit. Casa Cărţii de Ştiinţă, Cluj-Napoca.

20. Sprague, R., Carlson, E. (1982), Building Effective Decision Support Systems, Prentice Hall, Englewood Cliffs.

21. Stănescu, V. Al., Drobot, R. (2002), Măsuri nestructurale de gestiune a inundaţiilor [Non-structural measures of flood management], Edit. $\mathrm{H}^{*} \mathrm{G}^{*} \mathrm{~A}^{*}$, Bucureşti 
22. Şelărescu M., Podani M. (1993), Apărarea impotriva inundaţiilor [Defense against floods], Edit. Ştiinţifică, Bucureşti

23. Şerban, Gh. (2007), Lacurile de acumulare din bazinul superior al Someşului Mic. Studiu hidrogeografic [Reservoirs in the upper basin of Somesul Mic. Hydrogeographical study], Edit. Presa Universitară Clujeană, Cluj-Napoca, p. 236.

24. Şerban, Gh., Sorocovschi, V., Fodorean, I. (2004) Riscuri induse de amenajarea hidrotehnică a iazurilor de pe Valea Şesului (Câmpia Transilvaniei). În „Riscuri şi catastrofe", Editor Sorocovschi, V., Vol. III, Edit. Casa Cărţii de Ştiinţă, Cluj-Napoca, pp. 159-170.

25. Şerban, Gh., Touchart, L. (2008) Un nouveau parc naturel autour d'un vieux lac artificiel: les enjeux d'une Roumanie en transition dans les Monts Apuseni. Géocarrefour, „Les Parcs nationaux entre protection durable et développement local “, Volume 82, No 4, l'Association des Amis de la Revue de Géographie de Lyon, Université Jean Moulin - Lyon 3, pp. 243 - 253.

26. Șerban, P., Gălie, A. (2006), Managementul apelor. Principii și reglementări europene [Water management. European guidelines and regulations], Edit. Tipored, București

27. Todini, E. (1999), An operational decision support system for flood risk mapping, forecasting and management. Urban Water, Volume 1, Issue 2, 131-143, https://doi.org/10.1016/S1462-0758(00)00010-8

28. *** (1971 - 1979) Soil Map of R.S. Romania (in Romanian), 1:200000, ICPA, Bucureşti

29. *** (1978-1982), Topographic Map of Romania (in Romanian), 1:25000. Military Topographic Direction, Bucharest.

30. *** (1980), Indrumări metodologice şi tehnice pentru reconstituirea scurgerii naturale a râurilor [Methodological and technical guidelines for reconstructing the natural flow of rivers], IMH, Bucureşti

31. *** (1988), Indrumar pentru studiul complex al lacurilor de acumulare, [A guide for the complex study of reservoirs], I.M.H., Bucureşti.

32.*** (1992) The Atlas of Water Cadastre of Romania (in Romanian), Ministry of Environment and Aquaproject S.A., Bucureşti, 683 p.

33. *** (2018), Corine Land Cover 2018, https://land.copernicus.eu/pan-european/corineland-cover/clc2018.

34. *** (2019), Agenția Națională de Cadastru și Publicitate Imobiliară (ANCPI) [National Agency for Cadastre and Real Estate Advertising], http://geoportal.ancpi.ro/geoportal/viewer/index.html.

35. *** (2019), National Climatic Data Center, https://www.ncdc.noaa.gov/isd

36. *** (2019), RP5, https://rp5.ru/

37. *** (2019), ECA\&D: European Climate Assessment \& Dataset, https://www.ecad.eu/

38. *** Records of S.T.W.B.A. \& Maramureș W.M.S. ("Someș-Tisa" Water Basin Administration \& Maramureș Water Management System - in Romanian)

39. *** (2015), The Plan for the Prevention, Protection and Mitigation of the Flood Effects in the Somes-Tisa River Basin, national project funded by AXA 5 POS Mediu. 
